FIU Law Review

\title{
Reflections on the International Law Commission and Its Role in World Affairs
}

Jeffrey S. Morton

Professor of Political Science, Florida Atlantic University; Ph.D., University of South Carolina, jmorton@fau.edu

Follow this and additional works at: https://ecollections.law.fiu.edu/lawreview

Part of the International Law Commons

Online ISSN: 2643-7759

\section{Recommended Citation}

Jeffrey S. Morton, Reflections on the International Law Commission and Its Role in World Affairs, 13 FIU L. Rev. 1065 (2019).

DOI: https://dx.doi.org/10.25148/lawrev.13.6.9

This Article is brought to you for free and open access by eCollections. It has been accepted for inclusion in FIU Law Review by an authorized editor of eCollections. For more information, please contact lisdavis@fiu.edu. 


\title{
REFLECTIONS ON THE INTERNATIONAL LAW COMMISSION AND ITS ROLE IN WORLD AFFAIRS
}

\begin{abstract}
Jeffrey S. Morton*
I first became acquainted with the International Law Commission (ILC) in 1986 when I was selected to participate in the ILC's International Law Training Seminar (Seminar). The three-week Seminar, which is housed in the United Nations (UN) European Headquarters in Geneva each summer, brings together 24 young professionals to expose them to the ILC's work and train them in the field of international law. The Seminar, like the ILC, limits participation to one person per nationality. To be selected as the American member of the Seminar was a tremendous honor, and the experience in Geneva that summer marked a major turning point in my career. Started in 1966, the ILC's summer Seminar has provided training to more than 1,000 aspiring international lawyers, academics, and government officials.

The Seminar met as a group each morning and received lectures from members of the ILC. We were hosted by the mayor of Geneva and participated in site visits to many of the international organizations that are headquartered in the city. During the afternoon, Seminar students sat in on ILC debates, which provided us with a first-hand experience of how the ILC codifies and progressively develops international law. Because the room used by the ILC for its work is modest in size, Seminar students sat within a few feet of ILC members. The attitude of ILC members was always collegial and hospitable; they often went out of their way to introduce themselves to us and were often curious about our interests and career paths. My most memorable exchange with an ILC member occurred when Ambassador Abdul Koroma of Sierra Leone, a future judge on the International Court of Justice, placed his hand on my shoulder and said, "I was a member of the Law Commission's Summer Training Seminar when I was about your age, perhaps when you are my age you will be a member of the Commission."

Watching the ILC operate over the course of the summer of 1986, I was struck by the intellectual power in the room. Future UN Secretary General Boutros Boutros-Ghali of Egypt demonstrated a sharpness of mind that I've yet to see others parallel. Gaetan Arangio-Ruiz (Italy), Laurel Francis (Jamaica), Jiahua Huang (China), Ahmed Mahiou (Lebanon), Paul Reuter (France), Willem Riphagen (Netherlands), Abdul Koroma (Sierra Leone), Sir Ian Sinclair (United Kingdom), Sompong Sucharitkul (Thailand) and Nikoai
\end{abstract}

* Professor of Political Science, Florida Atlantic University; Ph.D., University of South Carolina, 1995; M.A., Rutgers University, 1991; B.A., University of North Carolina at Charlotte, 1987. 
Ushakov (Soviet Union) are ILC members that particularly stick out in my memory as being of remarkable legal mind.

In addition to the formal morning and afternoon sessions at the UN headquarters, I was also invited to four lunch and/or dinner parties hosted by ILC members. These occasions were opportunities to interact with ILC members, and oftentimes their families, in a casual environment.

Elected by the General Assembly for five-year terms, ILC members are charged with debating key deficiencies in international law, suggesting the codification of existing customary law, and advancing or progressively developing international law into new areas. Throughout our training, we were reminded that ILC members serve in a personal capacity, not as representatives of their respective governments. The historical record shows that a majority of ILC members tasked after World War II to create the ILC argued in favor of the need for "obtaining a scientific restatement of the law by independent experts . . . selected purely on their individual capacities and in no sense as representatives of governments." It was argued that political appointments should be avoided. Articles 2 and 8 of the ILC Statute implicitly reflect the desire of the drafting committee to staff the ILC with independent members. "Paragraph one of Article 2 states that the [ILC] shall consist of members who shall be persons of recognized competence in international law, while Article 8 states that the electors shall bear in mind that the persons to be elected to the commission should individually possess the qualifications required (emphasis added)."2 A proposal directly linking ILC members to their home governments, offered by those who feared that independent members would become detached from the governments that would ratify and enforce the international law that the ILC debated, was rejected by the drafting committee.

Separating ILC members from their home governments, however, was far from complete. The very process by which ILC members are elected creates a link between governments and members. The ILC Statute outlines the procedure by which individuals are elected as ILC members, requiring that candidates be nominated by member states of the UN. It is illogical to assume that governments would nominate an individual to be considered for an ILC seat if they were not confident that the individual would reflect the interests of the state. In addition to the nomination of one of its nationals to the ILC, governments must also lobby others in order to secure sufficient support in the General Assembly for their nominee to be elected to the ILC. As such, the process by which ILC members are selected creates either a link

HERBERT W. BRiggS, THE INTERNATIONAL LAW COMMISSION 30 (1960).

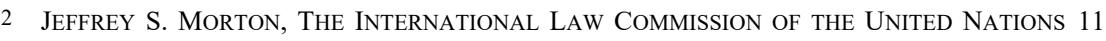
(2000). 
with their nominating government or virtually insures that the ILC member and her/his government will be in agreement in their jurisprudence.

During the summer of 1986 as I observed the ILC function, in both formal and informal sessions, I was struck by the extent to which its members appeared to reflect the general geostrategic stances taken by their home governments. Eastern Bloc members seemed to follow the lead of the Soviet Union member, rarely challenging each other on legal principle, while the ILC members from the Western bloc tended to unify around countering members from the East. Members from Latin America, Africa and Asia raised North-South issues, much as their home governments did in overtly political institutions such as the UN General Assembly.

Throughout my graduate studies, I remained in contact with many of the ILC members and UN officials, particularly from the Office of the UnderSecretary-General for Legal Affairs, that I had encountered in the summer of 1986. We discussed the tendency of ILC members, at times, to act in ways highly consistent with the governments that had nominated them to the ILC. I reviewed the scholarly literature on the ILC and found little reference to the status of its members as acting in individual capacity or as representatives of their governments. I subsequently decided to draft my doctoral dissertation on the ILC and systematically test the extent to which its members function independently from their home governments.

In the late 1980s, international law as a field of study within political science was on life support. Once the center of the study of international relations, when mostly every subfield of international relations (international law, international organization, and foreign policy) was taught using an international law textbook, the field had fallen on hard times since the 1930s. There are two particular reasons for the decline of the field. First, international law and its advocates were effectively vilified as causes of the Second World War. Not only did political realists argue that international law and the institutions that it created, such as the League of Nations (League), failed to prevent the rise of Hitler and Imperial Japan, but they were responsible for having blinded the status quo powers (United States, United Kingdom, France) to the rising danger. Realists, beginning with E.H. Carr (1939) and continuing until and beyond Hans J. Morgenthau (1948), placed the blame of World War II on idealists, international lawyers, and supporters of the League. ${ }^{3}$ The second reason for the rapid decline of international law as a field of academic endeavor after 1945 was the rise of the Cold War. Conversations about international law, cooperation, or peace among nations was a luxury, political and academic leaders argued, when confronting a

3 Edward Hallett Carr, The Twenty Years' Crisis, 1919-1939 (1939); Hans J. Morgenthau, Politics Among Nations: The Struggle for Power and Peace (1948). 
global menace such as the Union of Soviet Socialist Republics (U.S.S.R.). It was not until the 1990s, when the Soviet Union collapsed and the Communist International was exposed for all of its weaknesses, that students regained interest in international law. The challenge was finding international law courses taught by professors with training in international law. After spending half a century out of favor, there was a dearth of political science professors whose area of expertise was international law. If someone wanted to become a professor of international law during the Cold War, they gravitated to law schools, which very quickly became the epicenters for the field. Even at flagship research universities, it was not unusual to have no international law professors. When I informed the Graduate Committee at the University of South Carolina in 1991 that I had selected international law as my area of focus, the response was, "We've never had a student concentrate in that field."

This is not to say that there were no international law experts in academia or that meaningful research in the field was not taking place after World War II. International law was such a popular field of study after World War I that there were many tenured professors who remained in their posts well into the 1970s. They were, however, out of step methodologically with the field of political science. Beginning in the 1960s, Departments of Politics and Departments of Government began changing their names to Departments of Political Science. Swept up by the behavior revolution, professors of politics sought to emulate the hard sciences, or at least psychology, in their search for truth and knowledge. Our focus turned to quantifiable observations, assigning numbers to human behavior and then using sophisticated mathematical formulas to measure associations between variables. Whether the shift from a traditional methodology, which utilized insights and was largely descriptive, to the systematic analysis of data associated with the positivist/behavioral approach was productive for the field of international relations is an important, yet distinct, consideration. What is clear is the impact of adoption of quantitative methods on the subfield of international law. With tenured academics in international law trained in the traditional method, little interest was found among them to learn statistical analysis and change their mode of investigation. As a result, as the behavioral revolution took hold in political science, international law scholars fell increasingly behind the times as the Cold War unfolded.

By the late 1980s, as the international arena underwent dramatic change, graduate students interested in international law entered the field with the requisite training in data collection, analysis, and statistical models. Those of us who sought to resurrect the reputation of international law, as the postCold War environment emerged, did so from a "scientific" training perspective. 
A review of the scholarly literature of the ILC in 1990 revealed a field dominated by the writings of ILC members, government officials, and academics who relied upon the traditional research methodology. ${ }^{4}$ They described what the ILC was working on, analyzed the reports generated by the ILC, and suggested areas of international law in need of codification and progressive development. There was no systematic, data-based analysis of the ILC and the way that it functioned. My dissertation sought to fill that gap in the literature, make a statement about the applicability of statistical analysis in the field of international law, and uncover discernable patterns in the ILC process.

My dissertation and the book manuscript that it produced analyzed debate within the ILC in order to answer a set of questions:

1. Is the ILC insulated from world politics or a microcosm of it?

2. Has the Cold War's end affected the functioning of the ILC?

The second question obviously depends on the findings from testing the first. If the ILC was found to be insulated from world politics, specifically from the home governments of ILC members, the Cold War's end would have limited impact on the process by which the ILC functions.

Measuring the extent to which ILC members function in a personal capacity or in a way that reflects their governments requires a coding of their interactions with each other. Since the ILC does not vote on the issues that its members debate, the recorded discussions of the body were coded on a five-point scale that ranges from disagreement to agreement.

A code sheet was developed that includes several variables relating to ILC debate.

Table 1. Code Sheet. ${ }^{5}$

\begin{tabular}{|l|l|l|l|l|l|l|l|l|}
\hline Year & Meeting & Member & State & Era & $\begin{array}{c}\text { Bloc } \\
\text { Speaking }\end{array}$ & $\begin{array}{c}\text { Bloc } \\
\text { Targeted }\end{array}$ & Topic & Code \\
\hline & & & & & & & & \\
\hline
\end{tabular}

As noted earlier, the Code category measures the degree of agreement and disagreement among ILC members. A score of one (1) indicates complete disagreement while a code of five (5) indicates complete agreement with another ILC member. Three (3) reflects a neutral statement directed towards another ILC member, with two (2) and four (4) indicating non-

4 Jeffrey S. Morton, The International Law Commission of the United Nations: Legal Vacuum or Microcosm of World Politics, 23 InT'L INTERACTIONS 1, 37-54 (1997).

5 MORTON, supra note 2, at 82. 
neutral positions between the extremes (complete disagreement, complete agreement).

The topics that were selected to analyze ILC debate were the Draft Code of Crimes Against the Peace and Security of Mankind ("Draft Code of Crimes") and the Statute of the International Criminal Court ("Criminal Court Statute"). The Draft Code of Crimes was debated in the ILC between 1983 and 1989 (Cold War Era) and the Criminal Court Statute was debated between 1990 and 1991 (Post-Cold War Era). Each time that an ILC member specifically referenced a statement made by another during debate on the two issues the statement was coded according to the degree of agreement or disagreement. A total of 1,551 statements were coded, with 1,121 statements coded on the Draft Code of Crimes Against the Peace and Security of Mankind and 430 statements coded on the Statute of the International Criminal Court Statute. This large-N study provides sufficient data for a systematic empirical analysis of ILC debate with a high level of statistical confidence.

Based upon their nationality, ILC members were categorized based upon their country's geographic bloc. Five regional blocs are utilized by the $\mathrm{UN}$ in various organizational fora to promote geographical balance in membership. The five regional blocs are Africa, Asia, Eastern Europe, Latin America \& Caribbean, and Western Europe \& Others Group (WEOG). It is well established that governments form regional alliances in the UN system. What this study addresses is the extent to which ILC members do the same.

For both the Cold War Era (Draft Code of Crimes) and Post-Cold War Era (Criminal Court Statute) two measures were examined: Intra-Bloc and Inter-Bloc. Intra-Bloc interaction is measured by examining statements made by ILC members that were directed towards other ILC members from the same regional bloc. Inter-Bloc interaction is coded when members address their comments towards ILC members from a different regional bloc.

During the Cold War Era, there were 149 Intra-Bloc statements by ILC members coded. Table 2 reveals the degree of consensus and disagreement among ILC members when they directly comment on the positions taken by other members from the same regional bloc.

Table 2. Cold War Intra-Bloc ILC Debate. ${ }^{6}$

\begin{tabular}{|c|c|c|c|}
\hline Regional Bloc & Mean & N & Standard Deviation \\
\hline Western & 4.110 & 89 & 1.28309 \\
\hline Eastern & 5.000 & 14 & 0.00000 \\
\hline Latin America & 4.200 & 25 & 1.22474 \\
\hline
\end{tabular}

6 Morton, supra note 4 , at 47. 


\begin{tabular}{|c|c|c|c|}
\hline African & 4.500 & 14 & 0.85485 \\
\hline Asian & 4.333 & 7 & 1.07542 \\
\hline
\end{tabular}

According to the data, the Eastern Bloc of ILC members stated strong agreement with other Eastern Bloc members consistently and without exception. A standard deviation of zero (0) reveals perfect agreement of Eastern Bloc members throughout the Cold War Era on the Draft Code of Crimes topic debate. Lower levels of Intra-Bloc agreement were found with each of the remaining regional blocs. This initial finding aligns with geopolitics during the Cold War Era when Soviet domination of its sphere of influence resulted in a highly unified bloc.

To determine whether ILC debate, and the perfect consensus among Eastern Bloc members, changed as a result of the Cold War's end data from 1990-91 (Criminal Court Statute) is presented in Table 3.

Table 3. Intra-Bloc ILC Debate, Cold and Post-Cold War Eras. ${ }^{7}$

\begin{tabular}{|c|c|c|c|}
\hline Bloc & Cold War Rating & Post-Cold War Rating & $\%$ Change \\
\hline Western & 4.11 & 3.67 & -10.00 \\
\hline Eastern & 5.00 & 3.50 & -30.0 \\
\hline Latin America & 4.20 & 4.00 & -4.76 \\
\hline Asian & 4.50 & 4.60 & +2.22 \\
\hline African & 4.33 & 3.55 & -21.11 \\
\hline Overall & 4.25 & 4.33 & +1.64 \\
\hline
\end{tabular}

The data reveal that, overall, little changed in ILC debate in the postCold War era. The overall change in agreement was $1.64 \%$, indicating that only a modest increase in agreement occurred after the Cold War ended. A closer examination of the data, however, indicates that the bloc that experienced the greatest change was the Eastern Bloc. While ILC members from the East European bloc experienced complete agreement with one another during the 1983-1989 period, their consensus collapsed in the aftermath of the Cold War's end (3.5). The decline in agreement in the Eastern Bloc (-30\%) was greatest among all regional groupings.

While measuring intra-bloc ILC debate provides insights into the extent to which the ILC reflects the larger international arena, an examination of debate across regional groupings further supports the proposition that the ILC is reflective of international politics. A total of 545 ILC statements during the Cold War Era were directed by one ILC member to another from a different regional bloc (Inter-Bloc debate). Because the Cold War's end had the

7 MORTON, supra note 2, at 94. 
greatest initial impact on East-West relations, Inter-Bloc debate between those two regional blocs is presented in Table 4.

Table 4. East-West Inter-Bloc Debate, Cold War \& Post-Cold War Eras.

\begin{tabular}{|c|c|c|c|}
\hline Bloc Dyads & Cold War Era & Post-Cold War Era & \% Change \\
\hline East-West & $2.90(90)$ & $3.83(60)$ & +32 \\
\hline All Inter-Bloc & $3.48(543)$ & $3.76(271)$ & +8.04 \\
\hline
\end{tabular}

The data reveal that a dramatic change in interaction between ILC members occurred in the post-Cold War era. While overall inter-bloc ILC debate became more consensual in the post-Cold War era $(+8.04 \%)$, agreement across the East-West divide improved substantially $(+32 \%)$ after the Cold War.

A further investigation of the data indicates that the change in the EastWest divide was not evenly distributed. Statements made by Western bloc ILC members directed toward their East European counterparts improved from 3.16 (Cold War era) to 3.53 (post-Cold War era), while statements made by East European ILC members directed towards Western bloc members increased from 2.66 (Cold War) to 3.77 (post-Cold War era). ${ }^{8}$ Just as nations from Eastern Europe responded to the Cold War's end by seeking accommodation with the West in an effort to emulate western values and form of government, Eastern Bloc ILC members rapidly fell into agreement with Western European members in ILC debate. The evidence provides strong indication that the ILC, far from being insulated from world politics is, rather, closely tied to changes in the international political order.

The data collected and analyzed also reveals changes in ILC debate beyond the East-West divide. Table 5 shows changes in ILC debate between the two eras (Cold War, post-Cold War) for East-West, North-South and South-South agreement.

Table 5. Dialogue Rating for Key Relationships, Cold War and Post-Cold War Eras.

\begin{tabular}{|c|c|c|}
\hline Supra-Regional Dyads & Cold War & Post-Cold War \\
\hline Overall & 3.66 & 3.74 \\
\hline East-West & 2.90 & 3.83 \\
\hline North-South & 3.69 & 3.78 \\
\hline South-South & 4.14 & 3.76 \\
\hline
\end{tabular}

In three measures (Overall, East-West, North-South), ILC members experienced an increase in agreement during inter-bloc discussions, while

$8 \quad$ Id. at 98. 
debate exclusively between members from the South (Africa, Asia, Latin America) experienced a decline in agreement in the post-Cold War era.

Established after World War II to promote the codification and progressive development of international law, the ILC has the been the subject of debate for the entirely of its 70-year existence. One area of discourse has revolved around the nature of the ILC as either an insulated chamber where legal experts suggest the direction of international rules or, conversely, an extension of governments in pursuit of the same important goal. The data collected and analyzed in this study calls into question the insulation argument and appears to verify that the ILC is a microcosm of world politics. A clear and hostile East-West divide was reflected in ILC debate during the Cold War era, a relationship that changed dramatically in the post-Cold war era. North-South relations in the ILC, as was the case in international politics, improved in the ILC after the Cold War's end, and southern unity, a mainstay of Cold War world politics, declined in the postCold War era.

It is left to us to determine whether the intrusion of world politics into the ILC is positive or negative. If the ILC is a mere extension of nation-states, it can be argued, it is in need of repair. To reach a conclusion that the ILC is not useful by virtue of the intrusion of world politics, however, fails to take into account important legal considerations. As a body that codifies international law with careful concern over the acceptance of its documents by nation-states, the final drafts produced by the ILC stand a greater chance of becoming binding international law.

The study undertaken here is limited in scope. It considers two related topics, the Draft Code of Crimes Against the Peace and Security of Mankind and the Statute of the International Criminal Court, for a brief period of time (1983-1991). Similar studies of the ILC's work both prior to and following the temporal domain of this study may shed further light on the nature of the ILC debate processes. 